\title{
INOVASI PEMBELAJARAN SOSIOLOGI KURIKULUM 2013 MELALUI PENGEMBANGAN MEDIA PEMBELAJARAN BERBASIS TEKNOLOGI INFORMASI
}

\author{
Nur Endah Januarti ${ }^{1}$ dan Grendi Hendrastomo ${ }^{2}$
}

\begin{abstract}
Abstrak
Artikel ini bertujuan membahas kajian inovasi pembelajaran sosiologi melalui pengembangan media pembelajaran berbasis teknologi informasi bagi guru SMA/MA di Kabupaten Gunungkidul. Hal ini dilatarbelakangi oleh berlakunya Kurikulum 2013 secara serentak di Gunungkidul pada tahun 2017 sehingga guru perlu mengembangkan pembelajaran inovatif melalui media pembelajaran berbasis teknologi informasi. Subjek yang terlibat adalah guru sosiologi, peserta didik, kepala balai pendidikan menengah dan nonformal setempat, pengawas guru/sekolah, dan dosen. Teknik pengumpulan data melalui metode interview, focus group discussion, praktek, dan simulasi. Data dianalisis dengan pendekatan kualitatif deskriptif. Hasil pembahasan mendeskripsikan 1) Permasalahan Pembelajaran Sosiologi berbasis Kurikulum 2013 di Kabupaten Gunungkidul berkaitan dengan kebutuhan pengembangan media pembelajaran; 2) Inovasi Pembelajaran Sosiologi SMA/MA di Kabupaten Gunungkidul dilaksanakan dengan pengembangan media pembelajaran berbasis teknologi informasi; 3) Pengembangan media pembelajaran berbasis teknologi informasi dalam bentuk video pembelajaran dengan aplikasi movie maker dan hasil pengembangan media dapat menunjang praktek pembelajaran sosiologi bagi siswa.
\end{abstract}

Kata kunci : Kurikulum 2013; media pembelajaran; sosiologi; teknologi informasi; video pembelajaran

\footnotetext{
1 Dosen Pendidikan Sosiologi, Universitas Negeri Yogyakarta, Indonesi, email : endahjanuarti@uny.ac.id

2 Dosen Pendidikan Sosiologi, Universitas Negeri Yogyakarta, Indonesia, email:ghendrastomo@uny.ac.id
} 


\section{PENDAHULUAN}

Kurikulum 2013 mengembangkan 2 aspek sistem pembelajaran langsung dan tidak langsung. Proses pembelajaran langsung merupakan proses yang mengembangkan pengetahuan, kemampuan berpikir dan keterampilan psikomotorik melalui interaksi langsung dengan sumber belajar yang telah dirancang dalam kegiatan pembelajaran. Pembelajaran tidak langsung mencakup proses pendidikan yang terjadi selama proses pembelajaran langsung tetapi tidak dirancang dalam kegiatan khusus dan berkenaan dengan pengembangan nilai dan sikap. Interaksi langsung peserta didik dalam pembelajaran langsung menjadi satu komponen yang tidak dapat ditinggalkan karena pada proses pembelajaran Kurikulum 2013 menekankan pada telaah ilmiah (scientific). Sumber belajar dapat diperoleh melalui media, bahan ajar atau sumber belajar langsung di lapangan.

Media merupakan bagian yang tidak terpisahkan dari proses belajar mengajar. sebagai sumber belajar (Azhar Arsyad, 2014:2). Perkembangan ilmu pengetahuan dan teknologi semakin mendorong upaya pembaruan dalam pemanfaatan media pembelajaran sebagai sumber belajar siswa. Siswa yang dihadapi guru saat ini merupakan generasi yang dekat dengan hal tersebut. Proses belajar mengajar di sekolah setidaknya dapat menyesuaikan perkembangan diantaranya media pembelajaran. Media pembelajaran menjadi salah satu alternatif sumber belajar yang saat ini dapat dikembangkan bagi guru. Oleh karena itu guru dituntut untuk dapat menggunakan media dan mengembangkan keterampilan media pembelajaran. Guru dituntut memiliki pengetahuan dan pemahaman yang cukup tentang media pembelajaran.

Sosiologi merupakan salah satu mata pelajaran yang diberikan di SMA/ MA memiliki karakteristik yang menarik. Sebagai disiplin ilmu yang mengkaji masyarakat, realitas di masyarakat menjadi sumber belajar yang sangat relevan dengan mata pelajaran ini. Oleh karena itu kemampuan adaptif dari peserta didik dan guru sangat dibutuhkan dalam memahami berbagai perkembangan yang ada di masyarakat. Untuk mendekatkan realitas di lingkungan sosial dengan proses belajar mengajar di kelas, media pembelajaran menjadi faktor yang cukup berperan dalam pembelajaran sosiologi. Media memiliki peran yang penting untuk dapat menghemat waktu belajar, memudahkan pemahaman, meningkatkan perhatian siswa, meningkatkan aktivitas siswa, dan mempertinggi daya ingat siswa (Sardiman, 2014). Media pembelajaran yang menarik dan inovatif menjadi alternatif dalam mengembangkan sumber belajar bagi siswa untuk dapat belajar sosiologi.

$$
\text { Perubahan kurikulum yang }
$$

diberlakukan dalam Sistem Pendidikan Nasional dari Kurikulum Tingkat Satuan 
Pendidikan (KTSP) menjadi Kurikulum 2013 membawa pengaruh yang cukup besar dalam proses pembelajaran. Perubahan model pembelajaran yang sebelumnya berbasis pada teacher oriented menjadi student oriented memberikan dampak dalam pengelolaan pembelajaran di kelas. Berbagai metode, media dan bahan ajar perlu disiapkan dengan baik dan inovatif agar mampu mencapai tujuan pembelajaran sesuai dengan karakteristik dalam Kurikulum 2013. Begitu pula dengan pembelajaran sosiologi. Seperti yang kita pahami bersama pembelajaran sosiologi memiliki obyek studi tentang masyarakat dan membahas realitas dalam masyarakat. Pengembangan inovasi pembelajaran sosiologi dalam Kurikulum 2013 perlu untuk direncanakan dengan matang oleh guru sehingga tercipta suasana pembelajaran menarik, menyenangkan dan berkualitas sesuai karakteristik Kurikulum 2013.

Pada tahun 2017 pembelajaran sosiologi SMA/MA di Kabupaten Gunungkidul diarahkan pada pembelajaran dengan Kurikulum 2013. Guru memerlukan persiapan yang matang dalam perencanaan pembelajaran salah satunya adalah pengembangan media. Untuk dapat menyelenggarakan kegiatan belajar mengajar dengan baik maka guru dituntut untuk dapat menggunakan media dan mengembangkan keterampilan media pembelajaran. Dalam hal ini makan hendaknya guru memiliki pengetahuan dan pemahaman yang cukup tentang media pembelajaran sehingga guru mampu mengembangkan media pembelajaran yang kreatif dan inovatif dan disesuaikan dengan tuntutan kurikulum serta perkembangan peserta didik. Pengetahuan dan pengalaman belajar yang dibangun peserta didik saat ini berasal dari lingkungan sekitar dan lingkungan sosial lain yang dapat diakses melalui berbagai media tersebut. Cukup banyak media yang relevan dengan tuntutan kurikulum serta perkembangan peserta didik saat ini salah satu diantaranya adalah media pembelajaran berbasis ekomedia dan teknologi informasi.

Grendi Hendrastomo dan Nur Endah januarti (2017) menyebutkan bahwa di dunia pendidikan teknologi memegang peran penting sebagai akselerasi peningkatan kualitas proses pembelajaran. Cara peserta didik untuk memperoleh pengetahuan dipermudah dengan akses teknologi melalui internet dengan dukungan berbagai gawai canggih yang sesuai dengan kebutuhan siswa. Peserta didik saat ini sudah melek teknologi yang dibuktikan dengan cara mereka memanfaatkan teknologi. Melihat perkembangan teknologi yang semakin relevan dengan dunia pendidikan maka pengembangan media pembelajaran berbasis teknologi informasi juga merupakan salah satu langkah penyelarasan dengan hal tersebut.

Menurut Kepala Balai Pendidikan Menengah Dinas Pendidikan Pemuda dan Olahraga Kabupaten Gunungkidul (2017) 
beberapa kelemahan implementasi pembelajaran Kurikulum 2013 di Kabupaten Gunungkidul adalah penyiapan guru-guru agar dapat melakukan inovasi pembelajaran. Guru perlu disiapkan sehingga mau dan mampu mengembangkan berbagai metode, media dan bahan pembelajaran. Perguruan tinggi memiliki peran yang cukup srategis dalam mengkaji permasalahan ini. Sebagai lingkungan pendidikan yang bertanggungjawab dalam pengembangan keilmuan dan keterampilan semua unsur yang terlibat dala proses pendidikan, perguruan tinggi perlu memiliki strategi dan pendekatan yang tepat untuk dapat membantu mewujudkan tujuan pendidikan terutama dalam Kurikulum 2013. Maka dalam hal ini perlu untuk mengetahui dan memahami bagaimana kajian inovasi pembelajaran yang dapat dilakukan oleh perguruan tinggi dan sekolah dalam rangka mengembangkan media pembelajaran berbasis teknologi informasi.

\section{METODOLOGI}

Tulisan ini merupakan kajian hasil analisis inovasi pembelajaran sosiologi melalui pengembangan media pembelajaran berbasis teknologi informasi bagi Guru Sosiologi Gunungkidul. Subyek melibatkan Guru Sosiologi yang tergabung dalam MGMP Sosiologi Gunungkidul, Balai Pendidikan Menengah Dinas Pendidikan Pemuda dan Olahraga Kabupaten Gunungkidul, dan Siswa
SMA 1 Pathuk. Metode dilaksanakan dengan interview, focus group discussion, praktek, dan simulasi. Data yang diperoleh dari proses pengembangan dianalisis menggunakan analisis secara kualitatif deskriptif. Analisis dilakukan untuk mendeskripsikan berbagai hasil kajian yang diperoleh dari tahapan pengembangan media pembelajaran berbasis teknologi informasi yang dilaksanakan di MGMP Sosiologi Kabupaten Gunungkidul. Menggunakan data-data berupa teks/ naskah akademik berupa bahan ajar, pedoman kegiatan, laporan kegiatan dan evaluasi hasil kegiatan. Berbagai hasil kegiatan tersebut sebagai sumber analisis kajian pengembangan media pembelajaran berbasis teknologi informasi bagi MGMP Sosiologi Kabupaten Gunungkidul.

\section{HASIL}

Kerangka kajian yang digunakan untuk menelaah inovasi pembelajaran yang dilakukan di Kabupaten Gunungkidul dalam rangka mengimplementasikan Kurikulum 2013 adalah dengan pengembangan media pembelajaran sosiologi berbasis teknologi informasi yang dilakukan oleh guru dan didampingi oleh perguruan tinggi sebagai bentuk tanggungjawab perguruan tinggi untuk mengembangkan keilmuan. Media pembelajaran yang dipilih adalah video 
pembelajaran dengan aplikasi movie maker.

kerangka pemikiran sebagai berikut :

Pada proses kajian dikembangkan melalui

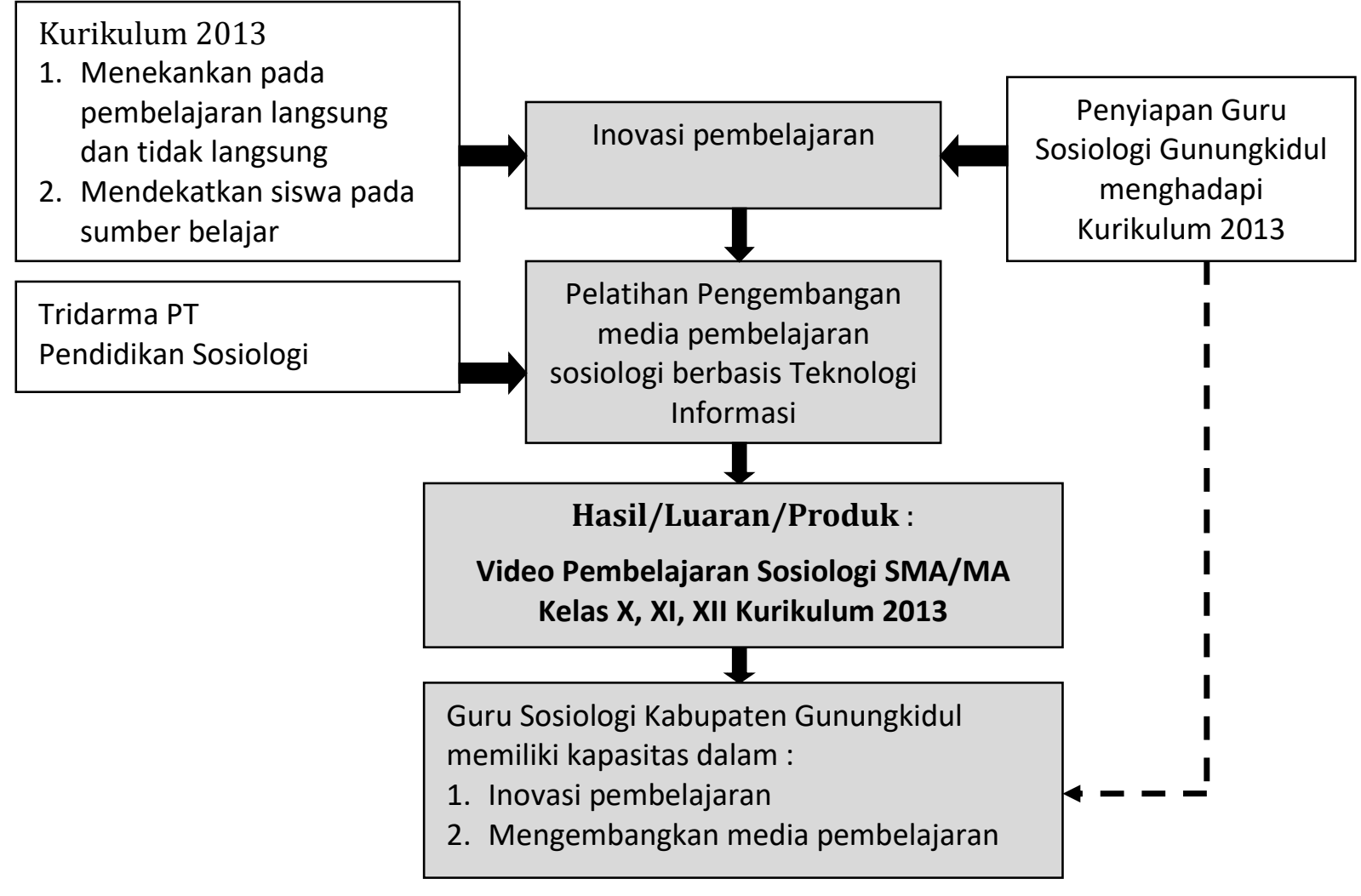

Gambar 1. Kerangka Pemecahan Masalah

Khalayak yang terlibat dalam proses ini adalah Balai Pendidikan Menengah Dinas Pendidikan Pemuda dan Olahraga Kabupaten Gunungkidul sebagai stakeholder/ pemerintah yang bertanggungjawab dalam kebijakan implementasi Kurikulum 2013, guru mata pelajaran sosiologi di Kabupaten Gunungkidul yang tergabung dalam MGMP Sosiologi Gunungkidul sebagai pendidik di sekolah, dan peserta didik sebagai pengguna media pembelajaran.

Melalui interview dan focus group discussion bersama Balai Pendidikan Menengah Dinas Pendidikan Pemuda dan Olahraga Kabupaten Gunungkidul, guru dan dosen diperoleh kajian tentang peluang dan tantangan pengembangan Kurikulum 2013 di Kabupaten Gunungkidul. Selanjutnya dirumuskan salah satu bentuk inovasi pembelajaran melalui pengembangan media pembelajaran berupa video pembelajaran materi pelajaran Sosiologi kelas X, XI, XII. Metode yang digunakan adalah dengan melakukan praktek pengembangan media terbimbing. Pada tahap akhir guru menyimulasikan dalam proses pembelajaran berbasis Kurikulum 2013 di kelas bersama peserta didik.

\section{DISKUSI}




\subsection{Permasalahan Pembelajaran Sosiologi Berbasis Kurikulum 2013 Di Kabupaten Gunungkidul}

Undang-Undang Nomor 20 Tahun

2003 tentang Sistem Pendidikan Nasional menyebutkan bahwa kurikulum adalah seperangkat rencana dan pengaturan mengenai tujuan, isi, dan bahan pelajaran serta cara yang digunakan sebagai pedoman penyelenggaraan kegiatan pembelajaran untuk mencapai tujuan pendidikan tertentu. Berdasarkan pengertian tersebut, ada dua dimensi kurikulum, yang pertama adalah rencana dan pengaturan mengenai tujuan, isi, dan bahan pelajaran, sedangkan yang kedua adalah cara yang digunakan untuk kegiatan pembelajaran. Kurikulum 2013 yang diberlakukan mulai tahun ajaran 2013/2014 memenuhi kedua dimensi tersebut.

Di Kabupaten Gunungkidul, Pembelajaran Sosiologi dengan Kurikulum 2013 mulai diberlakukan pada tahun ajaran 2014/2015. Namun dalam hal ini baru beberapa sekolah yang melaksanakan diantaranya SMA N 1 Wonosari, SMA N 2 Wonosari, SMA N 1 Karangmojo dan SMA N 2 Playen. Dari hasil interview bersama Guru Sosiologi di sekolah tersebut diperoleh beberapa simpulan terkait peluang dan tantangan implementasi pembelajaran sosiologi berbasis kurikulum 2013 di Kabupaten Gunungkidul.

Peluang yang dapat dikembangkan diantaranya sebagai berikut. Pertama, sumber belajar yang menarik dan relevan dalam pembelajaran yakni dinamika masyarakat Gunungkidul. Diantaranya perkembangan pariwisata yang relevan dengan materi pemberdayaan komunitas pada kelas XII. Selain itu fenomena bunuh diri dan tingginya pernikahan dini sebagai bahan kajian dalam gejala sosial pada kelas $X$. Berikutnya melekatnya nilai-nilai tradisi di Gunungkidul seperti Rasulan yang relevan dengan materi hubungan sosial pada kelas $X$. Berbagai perubahan sosial yang ada di Kabupaten Gunungkidul sebagai dampak pengembangan pariwisata sebagai bahan kajian pada kelas XII, dan lain sebagainya. Kedua, Sekolah memberi kesempatan kepada guru untuk dapat mengembangkan kompetensinya baik melalui forum MGMP maupun pelatihan. Hal ini dibuktikan dengan adanya alokasi waktu untuk MGMP setiap minimal 1 bulan sekali. Maka hal tersebut sebagai kesempatan bagi guruguru untuk dapat berdiskusi dan mengembangkan kompetensi bersama jaringan guru yang lain. Ketiga, lingkungan sekolah yang cukup luas. hal ini dilatarbelekangi oleh faktor geografis Kabupaten Gunungkidul yang memiliki kawasan lahan yang luas. maka guru dapat mengembangkan metode pembelajaran di luar kelas. Keempat, ketersediaan jaringan internet/wifi yang dapat dimanfaatkan dalam proses pembelajaran. Hal ini adalah salah satu bentuk teknologi yang selaras dengan implementasi pembelajaran Kurikulum 2013. 
Berkaitan erat dengan pengembangan sumber belajar dan media pembelajaran terutama berbasis teknologi informasi.

Namun selain berbagai peluang tersebut, SMA/MA dan guru di Kabupaten Gunungkidul memiliki kelemahan dalam implementasi pembelajaran sosiologi berbasis Kurikulum 2013. Disebutkan dari hasil FGD bersama MGMP Sosiologi berbagai kelemahan tersebut Pertama, peserta didik belum siap untuk dijadikan sebagai subjek pembelajar yang aktif. Hal ini dilatarbelakangi oleh motivasi peserta didik yang masih rendah. Kedua, orientasi pembelajaran masih pada Ujian Nasional. Seperti kita tahu bahwa sosiologi sebagai mata pelajaran yang diujikan dalam Ujian Nasional. Sekolah dan Dinas Pendidikan menjadikan orientasi pembelajaran adalah pada ketercapaian nilai kognitif yang mana menerjemahkan pembelajaran sosiologi dengan metode menghafal agar peserta didik dapat mengerjakan soal Ujian Nasional. Ketiga, faktor geografis yang membuat guru mengalami keterbatasan dalam mengakses sarana dalam MGMP untuk dapat berdiskusi dan mengevaluasi proses pembelajaran. Jarak antara satu sekolah dengan sekolah yang lain cukup jauh. Sarana yang disediakan forum MGMP untuk dapat bertemu dan berdiskusi minimal 1 bulan sekali jarang dimanfaatkan dengan maksimal oleh semua guru. Keempat, motivasi guru yang masih rendah disebabkan mayoritas guru adalah guru honorer. Meskipun hal ini tidak dapat dikatakan sebagai bentuk profesionalisme guru, namun hal ini adalah realita yang terjadi. Guru Sosiologi di Kabupaten Gunungkidul mayoritas adalah honorer yang notabene harus berupaya dengan sangat keras terkait pengembangan kompetensinya secara mandiri. hal ini menyebabkan keterbatasan pada guru honorer untuk mengembangkan berbagai inovasi pembelajaran karena beberapa kasus. Misal, 1 guru honorer harus mengajar di 3 sekolah dan keterbatasan sekolah dalam memfasilitasi inovasi pembelajarn bagi guru. Kelima, belum ada pelatihan pengembangan inovasi pembelajaran. Selama ini belum banyak pelatihan yang khusus diberikan untuk Guru Sosiologidalam mengembangkan metode, bahan ajar dan media pembelajaran. Sehingga guru masih mengalami keterbatasan dalam persiapan pembelajaran, implementasi dan evaluasi pembelajaran. Keenam, keterbatasan referensi meliputi materi atau personal. Guru Sosiologi di Kabupaten Gunungkidul memerlukan berbagai referensi bahan ajar, media pembelajaran dan praktek pembelajaran yang dapat dijadikan model dalam pembelajaran sosiologi berbasis Kurikulum 2013.

Pada tahun 2017/2018 secara serentak pembelajaran sosiologi Kurikulum 2013 diberlakukan bagi SMA/MA di Kabupaten Gunungkidul. Seperti yang kita pahami bersama bahwa Kurikulum 2013 menganut: 1) pembelajaran yang dilakukan guru (taught curriculum) dalam bentuk proses yang 
dikembangkan berupa kegiatan pembelajaran di sekolah, kelas, dan masyarakat; dan 2) pengalaman belajar langsung peserta didik (learned-curriculum) sesuai dengan latar belakang, karakteristik, dan kemampuan awal peserta didik. Pengalaman belajar langsung individual peserta didik menjadi hasil belajar bagi dirinya, sedangkan hasil belajar seluruh peserta didik menjadi hasil kurikulum. Kurikulum 2013 dirancang dengan karakteristik sebagai untuk mengembangkan keseimbangan antara pengembangan sikap spiritual dan sosial, rasa ingin tahu, kreativitas, kerja sama dengan kemampuan intelektual dan psikomotorik; pengalaman belajar terencana dimana peserta didik menerapkan apa yang dipelajari di sekolah ke masyarakat dan memanfaatkan masyarakat sebagai sumber belajar; pengembangkan sikap, pengetahuan, dan keterampilan serta menerapkannya dalam berbagai situasi di sekolah dan masyarakat; memberi waktu yang cukup leluasa untuk mengembangkan berbagai sikap, pengetahuan, dan keterampilan; pengembangan kompetensi yang dinyatakan dalam bentuk kompetensi inti dan kompetensi dasar.

Kurikulum 2013 dikembangkan berdasarkan faktor internal dan eksternal. Begitu pula di Kabupaten Gunungkidul. Dari hasil interview bersama Kepala Balai Pendidikan Menengah Dinas Pendidikan Pemuda dan Olahraga Kabupaten Gunungkidul dan pengawas guru mata pelajaran sosiologi Kabupaten Gunungkidul diperoleh informasi bahwa untuk dapat mengimplementasikan pembelajaran sosiologi berbasis Kurikulum 2013 sesuai dengan karekteristiknya sangat ditentukan oleh daya dukung faktor internal dan eksternal berbagai sekolah di Kabupaten Gunungkidul. Berbagai identifikasi permasalahan pembelajaran di Kabupaten Gunungkidul dalam implementasi pembelajaran sosiologi berbasis Kurikulum 2013 disebutkan sebagai bahwa 1) media pembelajaran diperlukan sebagai sumber belajar dalam proses pembelajaran langsung dalam Kurikulum 2013 SMA/MA di Kabupaten Gunungkidul; 2) Guru Sosiologi SMA/MA Kabupaten Gunungkidul dituntut memiliki pengetahuan dan pemahaman yang cukup tentang media pembelajaran; 3) Media pembelajaran menjadi faktor yang cukup berperan dalam pembelajaran sosiologi untuk mendekatkan realitas di lingkungan sosial di Gunungkidul dengan proses belajar mengajar di kelas; 4) Pada tahun 2017 pembelajaran sosiologi SMA/MA di Kabupaten Gunungkidul diarahkan pada pembelajaran dengan Kurikulum 2013 yang menuntut guru untuk menyiapkan perencanaan pembelajaran yang matang salah satunya dengan pengembangan media; 5) Guru-Guru Sosiologi SMA/MA Gunungkidul perlu dilatih secara intensif terkait dengan inovasi media pembelajaran sehingga dapat diimplementasikan dalam proses belajar 
mengajar; 6) Perguruan tinggi dapat berperan dalam menyiapkan Guru Sosiologi SMA/MA Kabupaten Gunungkidul yang profesional dengan memiliki kompetensi pedagogik, profesional, kepribadian, dan sosial.

\subsection{Inovasi Pembelajaran Sosiologi Melalui Pengembangan Media Pembelajaran Berbasis Teknologi Informasi Di Kabupaten Gunungkidul}

Inovasi pembelajaran merupakan PR guru pada saat ini. Pengembangan Kurikulum 2013 yang mengarah pada pembelajaran berorientasi pada peserta didik dengan model pembelajaran ilmiah (scientific learning) membuat guru perlu untuk berinovasi dalam menyiapkan berbagai strategi pembelajaran, metode pembelajaran, bahan ajar, dan media pembelajaran. Media pembelajaran merupakan sesuatu yang dapat digunakan untuk dapat menyampaikan pesan atau informasi pembelajaran dalam proses belajar mengajar sehingga merangsang perhatian dan minat siswa dalam belajar (Azhar Arsyad, 2014:10). Agar proses belajar mengajar dapat berhasil dengan baik, siswa sebaiknya diajak untuk memanfaatkan semua alat inderanya. Guru memiliki tugas untuk menampilkan rangsangan (stimulus) yang dapat diproses melalui media.

Media pembelajaran merupakan bagian dari sumber belajar. Sumber belajar adalah sumber-sumber yang mendukung proses pembelajaran termasuk sistem penunjang materi dan lingkungan pembelajaran (Seels dan Richey dalam Azhar Arsyad, 2014:8). Ketika media berfungsi sebagai sumber untuk membantu individu dalam proses pembelajaran misal video berisi materi atau bahan pembelajaran di dalam dan di luar kelas, maka kedudukan video sama dengan sumber belajar. Dalam proses belajar mengajar dua unsur yang amat penting adalah metode mengajar dan media pembelajaran. Hamalik (2010) mengemukakan bahwa pemakaian media pembelajaran dalam proses belajar mengajar dapat membangkitkan keinginan dan minat yang baru, membangkitkan motivasi dan rangsangan kegiatan belajar serta pengaruh psikologis kepada siswa. Penggunaan media pembelajaran pada saat orientasi pembelajaran akan sangat membantu keaktifan proses pembelajaran dan penyampaian pesan dan isi pembelajaran pada saat itu. Terdapat beberapa fungsi media pembelajaran khususnya media visual yaitu fungsi atensi, fungsi afektif, fungsi kognitif dan fungsi kompensatoris.

Pada saat ini terjadi perkembangan teknologi di dunia. Disebutkan oleh Grendi Hendrastomo dan Nur Endah Januarti (2017) bahwa salah satu teknologi yang ditemukan dan sampai saat ini begitu mencengangkan kehadirannya adalah internet. Internet membuat

perpindahan data digital menjadi sangat mudah, mengintegrasikan berbagai peralatan komputasi, dan membentuk jaringan menjadi sesuatu yang simpel. 
Perkembangan teknologi juga telah banyak mengubah perilaku dan budaya masyarakat. Salah satunya di bidang pendidikan, teknologi menjadi tantangan yang wajib dirangkul untuk mendorong percepatan dan peningkatan kualitas pendidikan. Selain itu teknologi diharapkan mampu mendorong efisiensi baik dalam proses pembelajaran, pendidikan maupun dalam proses pengajaran. Perkembangan ilmu pengetahuan dan teknologi tentunya mempengaruhi berbagai bentuk media pembelajaran. Keberadaan media pembelajaran berbasis teknologi informasi pada saat ini menjadi salah satu bentuk inovasi pembelajaran yang dapat digunakan oleh guru sebagai bentuk penyesuaian dalam perkembangan lingkungan eksternal pendidikan. Selain itu keberadaan media pembelajaran berbasis teknologi informasi harapannya mendorong upaya pembaruan dalam pemanfaatan media pembelajaran sebagai sumber belajar siswa yang sesuai dengan prinsip dasar Kurikulum 2013. Terakhir, faktor yang sangat relevan adalah peserta didik yang dihadapi guru saat ini merupakan generasi yang dekat dengan dunia teknologi. Maka, hal ini menjadi peluang bagi guru untuk dapat mengembangkan media pembelajaran sosiologi berbasis teknologi informasi.

Berdasarkan hasil interview dan FGD bersama Guru Sosiologi di Kabupaten
Gunungkidul (2017) diperoleh data bahwa selama ini guru-guru masih belum optimal dalam inovasi pembelajaran khususnya pengembangan media pembelajaran berbasis teknologi informasi. Hal ini disebabkan oleh beberapa hal yakni:

\subsubsection{Faktor Kemampuan}

Guru Sosiologi SMA/MA di Kabupaten Gunungkidul tidak semua memiliki kemampuan mumpuni dalam mengembangkan media pembelajaran berbasis IT. Hal ini selain karena belum banyak mengembangkan media pembelajaran berbasis IT juga disebabkan oleh faktor masih jarang pelatihan pengembangan media pembelajaran khususnya sosiologi yang berbasis IT.

\subsubsection{Faktor Geografis}

Secara geografis jarak antar sekolah di Kabupaten Gunungkidul berjauhan. Selain itu akses terkait internet antara sekolah yang satu dan sekolah yang lain berbeda-beda. Maka hal ini menyebabkan pengembangan media pembelajaran berbasis teknologi mengalami kendala.

\subsubsection{Faktor Motivasi}

Hal ini dilatarbelakangi oleh 2 hal yakni terkait jenjang karir dan faktor geografis. Perlu diketahui bahwa Guru Sosiologi di Kabupaten Gunungkidul yang berstatus PNS masih sangat sedikit. Kurang lebih hanya 8 guru yang berstatus PNS dari 34 guru sosiologi. Hal ini menyebabkan motivasi untuk mengembangkan karir bagi guru-guru 
non PNS masih sangat minim karena adanya anggapan bahwa inovasi pembelajaran hanya akan berdampak bagi guru PNS. Selain itu faktor geografis terkait jarak sekolah satu dengan yang lain yang cukup jauh membuat motivasi guru untuk berkumpul dalam forum MGMP juga terbatas.

\subsubsection{Faktor Siswa}

Hal ini disebabkan karena keinginan siswa untuk belajar tidak dapat disamakan dengan daerah lain. Orientasi siswa dalam pembelajaran sosiologi masih sekedar mengikuti pembelajaran karena diwajibkan sekolah. Bukan pada mengembangkan pengetahuan. Hal ini membuat guru cukup sulit untuk mengembangkan media pembelajaran berbasis teknologi informasi terutama jika mengembangkan media yang melibatkan siswa.

\subsubsection{Faktor Dukungan Sekolah}

Sarana dan prasarana sekolah tidak semuanya mendukung pengembangan media pembelajaran. Hal ini karena keterbatasan dana pengembangan sekolah. Selain itu tidak semua sekolah dapat mengalokasikan dukungan bagi guru dalam pengembangan kapasitas melalui kegiatan pelatihan.

Dari berbagai faktor tersebut dapat dianalisis bahwa pengembangan keterampilan dan pengetahuan guru terkait inovasi pembelajaran khususnya media pembelajaran berbasis teknologi informasi masih mengalami keterbatasan. Selain faktor internal terdapat juga faktor eksternal yang dihadapi guru. Hal ini tentunya akan menjadi hambatan dalam inovasi proses pembelajaran di sekolah. Perolehan pengetahuan dan keterampilan, perubahan sikap dan perilaku siswa pada saat belajar dapat terjadi karena interaksi antara pengalaman baru dan pengalaman yang pernah dialami sebelumnya. Menurut Bruner dalam Azhar Arsyad (2014) terdapat tiga tingkatan utama modus belajar yaitu pengalaman langsung, pengalaman piktorial/gambar, dan pengalaman abstrak. Ketiga pengalaman tersebut saling berinteraksi dalam merangkat pengetahuan baru . Tingkatan pengalaman tersebut merupakan perolehan hasil belajar melalui komunikasi. Materi yang disampaikan dan diinginkan siswa merupakan pesan yang bersumber dari berbagai sumber belajar. Keterbatasan guru dalam mengembangkan pengalaman dan pengetahuan menjadi permasalahan tersendiri dalam menuangkan pesan melalui berbagai simbol dan media pembelajaran.

Maka program pengembangan media pembelajaran berbasis teknologi informasi menjadi solusi yang kemudian dibutuhkan dalam hal ini. Dari hasil FGD bersama Balai Pendidikan Menengah dan Nonformal, pengawas guru, guru dan dosen maka diperoleh kesimpulan bahwa Guru Sosiologi Kabupaten Gunungkidul melakukan inovasi pembelajaran melalui pengembangan media pembelajaran berbasis teknologi informasi. Dimensi kurikulum, kompetensi guru, dan pembelajaran inovatif selaras dengan 
kebutuhan ketersediaan media pembelajaran yang mendukung pembelajaran. Oleh sebab itu dasar penyelenggaraan program pengembangan media pembelajaran berbasis teknologi informasi disesuaikan dengan prinsip Penyempurnaan Pola Pikir dalam Kurikulum 2013 di Kabupaten Gunungkidul melalui berbagai hal di bawah ini.

Pola pembelajaran yang berpusat pada guru menjadi pembelajaran berpusat pada peserta didik. Peserta didik harus memiliki pilihan-pilihan terhadap materi yang dipelajari untuk memiliki kompetensi yang sama. Hal ini disesuaikan dalam pengembangan video pembelajaran sosiologi sebagai media pembelajaran. Guru Sosiologi Kabupaten Gunungkidul harapannya akan lebih dapat memberikan kesempatan kepada peserta didik untuk memilih materi pembelajaran melalui berbagai ragam media. Bukan hanya dari buku atau bahan ajar yang ditentukan guru sebelumnya. Namun peserta didik akan memiliki alternatif dengan media pembelajaran yang dapat diakses melalui teknologi informasi. Karya guru dapat diunggah dan dapat dipelajari oleh peserta didik dimanapun dan kapanpun. Selain itu peserta didik akan memiliki referensi terkait materi tersebut.

Pola pembelajaran satu arah (interaksi guru-peserta didik) menjadi pembelajaran interaktif (interaktif gurupeserta didik-masyarakat-lingkungan alam, sumber/media lainnya). Tentunya hal ini sangat sesuai dengan program pengembangan media pembelajaran yang dilakukan. Pola pembelajaran interaktif dikembangkan tidak hanya dari peserta didik dan guru, melainkan melibatkan media pembelajaran. Hal ini tidak hanya akan terjadi ketika di dalam kelas, namun juga di luar kelas. Ketika di dalam kelas, guru akan melibatkan media pembelajaran berupa video pembelajaran tersebut pada saat proses pembelajaran. Fungsi video pembelajaran sebagai bahan pembelajaran. Selain itu peserta didik dapat mengakses bahan ajar melalui media pembelajaran yang diunggah guru melalui internet. Pada proses yang lain, guru dapat mengembangkan model pembuatan video pembelajaran sebagai strategi atau metode pembelajaran. Hal ini sangat sesuai dengan karaktersitik Kurikulum 2013. Terjadi proses ilmiah ketika siswa mendapat proyek untuk pembuatan video pembelajaran. Inilah bentuk Project based learning dalam Kurikulum 2013. Ketika peserta didik membuat video pembelajaran ada proses mengamati, menanya, menelaah, menganalisis, menyusun dan mempresentasikan hasil video pembelajaran. Maka mulai dari kemampuan guru mengembangkan video pembelaajaran akan menjadi referensi dalam mengembangkan strategi pembelajaran sosiologi. 
Pola pembelajaran terisolasi menjadi pembelajaran secara jejaring (peserta didik dapat menimba ilmu dari siapa saja dan dari mana saja yang dapat dihubungi serta diperoleh melalui internet). Pada program pengembangan media pembelajaran berbasis teknologi informasi bagi Guru Sosiologi di Gunungkidul tentu juga memiliki arah pada proses ini. Pembelajaran jejaring dengan konsep penggunaan internet. Hal ini dilakukan dengan proses pembuatan video pembelajaran yang mana guru mengakses berbagai materi melalui youtube atau video lain dan selanjutnya video tersebut diolah melalui aplikasi. Hal ini tentu melibatkan jejaring dengan berbagai sumber materi ajar yang diperoleh dari internet. Selanjutnya video pembelajaran karya guru tersebut yang diunggah dan kemudian dapat diakses oleh peserta didik sebagai materi pembelajaran.

Pola pembelajaran pasif menjadi pembelajaran aktif-mencari (pembelajaran siswa aktif mencari semakin diperkuat dengan model pembelajaran pendekatan sains). Pola ini dikembangkan tidak hanya bagi peserta didik namun juga guru. Proses guru mengembangkan media pembelajaran dengan menggunakan berbagai sumber belajar yang tidak hanya dari buku melainkan dari internet tentunya mendorong kemampuan guru untuk aktif mencari sumber bahan ajar. Pada tahap lain guru juga menelaah berbagai bahan ajar yang diperoleh dari internet. Hal ini tentunya karena tidak semua materi yang ada di internet merupakan materi yang valid. Maka guru melakukan proses analisis dan sintesis materi ajar tersebut. Di sisi lain bagi peserta didik memiliki kesempatan untuk mengakses berbagai materi juga tidak hanya dari buku, namun melalui contoh-contoh nyata dalam media pembelajaran berupa video. Bagi peserta didik usia SMA/MA belajar menggunakan media gerak juga memiliki keunggulan. Hal ini sesuai dengan teori yang dikemukakan oleh Edgar Dale dalam Cone of Learning (sparkinsight.com) tentang keaktifan dan pemahaman sebuah permasalahan. Jika peserta didik hanya membaca maka hanya menyerap sebesar 10\%. Peserta didik mendengar maka memuat 20\%. Jika dengan melihat maka memuat sebesar 30\%. Namun jika proses pembelajaran dilakukan dengan mengamati video dan peristiwa melalui film atau tayangan maka daya serap sebesar $50 \%$. Hal ini disebabkan anak mengalami proses mendengar dan melihat. Selanjutnya ketika peserta didik melanjutkan dengan mendiskusikan substansi yang dimuat dalam film/video maka daya serap sebesar $70 \%$ karena peserta didik turut mengemukakan pendapat.

Pola belajar sendiri menjadi belajar kelompok (berbasis tim) dan pola pembelajaran alat tunggal menjadi pembelajaran berbasis alat multimedia. Malcom Fleeming (1988) menjelaskan untuk menyampaikan pesan pendidikan, media 
sangat efektif untuk mengendalikan perhatian. Pada awalnya disebutkan bahwa keterbatasan pembelajaran sosiologi lebih pada mengutamakan peran guru, selain itu guru masih pesimis ketika pembelajaran diarahkan pada berorientasi pada peserta didik. Maka dengan media yang dikembangkan akan dapat menjadi bentuk pola pembelajaran yang menggunakan alat atau media sebagai sumber belalajar.

\section{Pola pembelajaran berbasis massal} menjadi kebutuhan pelanggan (users) dengan memperkuat pengembangan potensi khusus yang dimiliki setiap peserta didik. Ketika guru memiliki kemampuan dalam mengembangkan media pembelajaran maka bukan tidak mungkin akan dikembangkan pada metode project based learning yang sesuai dengan karakteristik pembelajaran Kurikulum 2013. Maka peserta didik dapat mengembangkan potensinya melalui pengembangan media atau sumber belajar bersama-sama guru. Pola pembelajaran ilmu pengetahuan tunggal (monodiscipline) menjadi pembelajaran ilmu pengetahuan jamak (multidisciplines). Hal yang jarang disadari bahwa pada proses inovasi pembelajaran dengan mengembangkan media pembelajaran sosiologi maka yang akan dipelajari bukan hanya materi atau aspek pengetahuan, namun telah mencakup aspek yang lain seperti keterampilan, nilai dan sikap. Contohnya keterampilan menggunakan alat, sikap menghargai antar anggota tim, nilai kejujuran dan tanggung jawab.

\section{Pola pembelajaran pasif menjadi} pembelajaran kritis. Peserta didik akan sangat aktif karena ketersediaan sumber belajar yang tidak hanya berasal dari guru melainkan dari media pembelajaran. Selain itu peserta didik akan dapat mengkaji secara lebih kritis terkait berbagai aspek yang dimunculkan dalam media pembelajaran berbasis teknologi informasi.

Maka video pembelajaran menjadi langkah pengembangan yang tepat dalam inovasi pembelajaran yang dilakukan bagi Guru SosiologiSMA/MA di Kabupaten Gunungkidul. Hal ini tentunya dapat dilaksanakan dengan memadukan pendampingan dari perguruan tinggi dalam pengkajian metode, materi dan media yang dikembangkan.

Langkah-langkah pengembangan juga menjadi faktor yang sangat menentukan dalam upaya inovasi pembelajaran sosiologi di Kabupaten Gunungkidul karena menciptakan inovasi pembelajaran sangat ditentukan oleh faktor internal dan eksternal. Dalam hal ini dipengaruhi oleh Guru Sosiologi di Kabupaten Gunungkidul sebagai pelaku, MGMP Sosiologi sebagai sarana pengembangan, Sekolah sebagai sarana pengembangan dan fasilitasi, Balai Pendidikan Menengah dan Nonformal sebagai pemangku kebijakan/sistem, pengawas sekolah sebagai 
evaluator dan peserta didik sebagai pengguna dalam pembelajaran.

\subsection{Pengembangan Media Pembelajaran} Berbasis Teknologi Informasi Melalui Video Pembelajaran Bagi Guru Sosiologi Sma/Ma Kabupaten Gunungkidul

Untuk dapat menciptakan inovasi pembelajaran sosiologi berbasis Kurikulum 2013 di Kabupaten Gunungkidul dengan pengembangan media pembelajaran teknologi informasi dilaksanakan melalui berbagai tahapan pengembangan. Hal ini agar dapat memperoleh bentuk inovasi pembelajaran yang sesuai dengan kebutuhan. Pengalaman beberapa guru yang sudah menggunakan Kurikulum 2013 dalam pembelajaran sebelumnya mengakui bahwa belum banyak menggunakan media pembelajaran apalagi mengembangkan media pembelajaran. Hal ini disadari pada proses belajar mengajar membuat bapak ibu guru tidak dapat maksimal dalam mengembangkan motivasi dan merangsang kegiatan belajar peserta didik. Pada saat guru-guru Kabupaten Gunungkidul diberikan pembahasan mengenai urgensi media pembelajaran terdapat inspirasi yang berkembang. Minat guru dalam mengembangkan media pembelajaran menjadi lebih besar.

Media pembelajaran dapat dihasilkan melalui berbagai cara yakni media teknologi cetak, audio visual, teknologi informasi/berbasis komputer dan gabungan media cetak serta komputer. Teknologi cetak merupakan cara menghasilkan media berupa buku, tulisan cetak atau fotografis. Teknologi audio visual merupakan cara menghasilkan media pembelajaran dengan mesin mekanis dan elektronik untuk menyajikan pesan audio dan visual. Teknologi berbasis komputer merupakan cara menghasilkan media dengan menggunakan sumber berbasis mikroprosesor. Informasi yang disampaikan dalam bentuk digital. Teknologi gabungan merupakan cara menghasilkan media pembelajaran dengan menggabungkan pemakaian beberapa bentuk media yang dikendalikan oleh komputer.

Berbagai jenis media dapat diklasifikasikan dalam beberapa kategori yakni cetak, visual, audio, permainan, realita, telekomunikasi, dan teknologi informasi. Salah satu langkah yang digunakan untuk mengembangkan media pada saat ini adalah dengan teknologi informasi berbasis internet. Segala sumber belajar dapat diperoleh melalui internet dan perangkat komputer. Berbagai audio, video dapat diakses dengan internet dan selanjutnya dioleh menggunakan aplikasi komputer untuk dapat mengembangkan media pembelajaran yang inovatif. Setelah mendapatkan berbagai materi terkait jenis media pembelajaran, guru-guru Sosiologi di Kabupaten Gunungkidul menginginkan pengembangan media yang dapat dilakukan oleh bapak ibu guru secara mandiri. Akhirnya pengembangan media pembelajaran dipilih 
menggunakan video pembelajaran dengan aplikasi movie maker.

Movie maker adalah aplikasi yang digunakan dalam mengembangkan video pembelajaran. Menggunakan perangkat komputer dan internet. Movie maker dipilih berdasarkan pertimbangan yakni 1) Bentuk aplikasi pengembangan video pembelajaran paling sederhana; 2) Dapat mengakses data video dari sumber yang sudah ada seperti youtube; 3) Bapak ibu Guru Sosiologi memiliki perangkat yang mendukung (laptop/komputer); 4) Sekolah memiliki layanan internet; 5) Video pembelajaran yang dikembangkan dapat diputar berulang-ulang di berbagai kelas; 6) Video pembelajaran yang dikembangkan tidak harus menggunakan internet saat akan diputar. Untuk melaksanakan inovasi pembelajaran melalui media pembelajaran berbasis teknologi informasi berupa pengembangan video pembelajaran bagi Guru SosiologiSMA/MA di Kabupaten Gunungkidul dilaksanakan dengan kegiatan Focus Group Discussion, Pelatihan Pengembangan Media Pembelajaran Berbasis Teknologi Informasi melalui praktek, Simulasi Pembelajaran, dan Evaluasi Hasil.

Langkah pertama, Focus Group Discussion. Langkah ini dilaksanakan guna menemukan pemahaman bersama tentang hakikat pembelajaran inovatif dan urgensi pengembangan media pembelajaran berbasis teknologi informasi. FGD dilaksanakan dalam beberapa tahap. Tahap pertama, FGD 1 yang dilaksanakan oleh dosen dan Balai Pendidikan Menengah Dinas Pendidikan Pemuda dan Olahraga Kabupaten Gunungkidul. Untuk mendiskusikan terkait kebijakan pengembangan implementasi Kurikulum 2013 di Kabupaten Gunungkidul. Dalam tahap ini diperoleh hasil simpulan bahwa peran perguruan tinggi sangat penting untuk mensinergiskan dan membantu balai pendidikan menengah dan nonformal dalam membangkitkan semangat serta motivasi guru melalui forum MGMP dan pelatihan peningkatan kompetensi guru. Tahap kedua, FGD 2 yang dilaksanakan oleh dosen, guru, dan pengawas sekolah. Untuk mendiskusikan terkait implementasi Kurikulum 2013 dalam pembelajaran sosiologi di Kabupaten Gunungkidul. Dari hasil FGD diperoleh hasil bahwa guru dapat memahami pentingnya inovasi pembelajaran dalam implementasi Kurikulum 2013; guru dapat mengembangkan berbagai metode, media dan bahan ajar dalam inovasi pembelajaran sosiologi berbasis Kurikulum 2013; guru aktif dalam forum MGMP; perguruan tinggi memiliki peran vital dalam mengintegrasikan unsur guru sebagai pendidik dan pengawas sekolah sebagai pemangku kebijakan, sehingga perguruan tinggi sebagai pengembang keilmuan yang diimplementasikan di sekolah. Tahap ketiga, FGD 3 yang dilaksanakan oleh dosen dan guru dalam MGMP sosiologi Gunungkidul. Untuk 
mendiskusikan format inovasi pembelajaran yang dapat dilakukan. Melalui analisis situasi dan kondisi, analisis masalah dan analisis materi dalam Kurikulum 2013. Dari hasil FGD diperoleh hasil bahwa Guru Sosiologi mengembangkan media pembelajaran berbasis Kurikulum 2013 berupa video pembelajaran. Hal ini dilatarbelakangi oleh 1) para guru memiliki kemampuan dasar dalam membuat media tersebut; 2) tersedianya alat; 3) dapat digunakan dalam pembelajaran di kelas. Materi yang dikembangkan adalah materi pelajaran sosiologi kelas X, XI, XII. Metode melalui praktek dan simulasi dalam pembelajaran.

Langkah kedua, pelatihan pengembangan media pembelajaran berbasis teknologi informasi melalui praktek. Langkah ini dilaksanakan dengan memberikan keterampilan pembuatan media berbasis teknologi informasi. Dari proses kajian diperoleh hasil bahwa keterampilan pembuatan media menjadi modal bagi guru untuk dapat membuat media pembelajaran berbasis teknologi informasi. Melalui praktek, dilakukan pembuatan video pembelajaran. Pada proses ini guru melakukan diskusi/ follow up materi yang diperoleh dalam pelatihan yang mana selanjutnya diaplikasikan dan diterapkan dalam praktek pengembangan media pembelajaran berbasis teknologi informasi. Alat yang dibutuhkan adalah komputer, laptop, jaringan internet, dan aplikasi movie maker. Dari hasil praktek diperoleh beberapa video pembelajaran yakni materi Perubahan Sosial, Kelompok Sosial, Konflik Sosial, Fungsi Sosiologi bagi Masyarakat, Perubahan Budaya di Indonesia. Pada proses ini diakhiri dengan presentasi dan evaluasi hasil produk oleh MGMP sehingga satu sama lain memperoleh masukan baik dari sisi materi, strategi dan metode pembelajaran.

Langkah ketiga, simulasi dalam pembelajaran. Hal ini dilaksanakan dengan diawali memilih salah satu video pembelajaran, guru serta kelas yang akan diujicobakan. Pada akhirnya diperoleh keputusan bahwa video pembelajaran dengan materi hakikat sosiologi untuk kelas $\mathrm{X}$ akan diujicobakan oleh Ibu Aprilia Nofitasari. Pada proses ini seperti tahapan yang dilakukan dalam Lesson Study yakni terdapat tahap plan, do, see. Sebelum melaksanakan praktek mengajar maka ibu Aprilia membuat RPP yang disesuaikan dengan materi, media dan metode yang dirancang (plan). Setelah itu simulasi pembelajaran dilaksanakan $(d o)$ di kelas X IIS SMA N 1 Pathuk. Jumlah peserta didik sebanyak 25 siswa. Pembelajaran dilaksanakan pada jam 09.15 - 10.45. Pada proses ini anggota MGMP yang lain mengamati di barisan belakang dengan melakukan evaluasi. Setelah selesai simulasi, dilaksanakan evaluasi dan diskusi bersama MGMP dan dosen (see).

Dari hasil pembelajaran diperoleh kesimpulan bahwa 1) video pembelajaran sangat menunjang dalam pembelajaran 
sosiologi kelas X Kurikulum 2013 materi hakikat sosiologi; 2) guru sangat terbantu dalam mengembangkan kemampuan peserta didik untuk aktif. Selain itu dari hasil pembelajaran disebutkan oleh salah satu siswa kelas $\mathrm{X}$ IIS bernama Rega bahwa pembelajaran menyenangkan dan tidak membosankan. Selanjutnya diungkapkan bahwa ternyata belajar Sosiologi dengan Kurikulum 2013 itu menyenangkan. Hal ini disampaikan dalam pernyataannya "Saya menjadi lebih mengerti materi yang didiskusikan. Selain itu dapat berlatih mengemukakan banyak pendapat dalam kegiatan diskusi tadi dan video $\mathrm{Bu}$ April bagus"ujarnya.

Langkah keempat, Evaluasi yang dilaksanakan dengan melakukan evaluasi proses dan hasil kegiatan inovasi pembelajaran dengan media pembelajaran berbasis teknologi informasi melalui pengembangan video pembelajaran bagi Guru Sosiologi di Kabupaten Gunungkidul. Dilaksanakan 2 bentuk evaluasi yakni evaluasi proses dan evaluasi hasil. Evaluasi proses dilakukan untuk mengetahui proses inovasi pembelajaran melalui pengembangan media pembelajaran. Dari hasil evaluasi diperoleh hasil bahwa guru dapat melakukan inovasi pembelajaran melalui pengembangan media pembelajaran berbasis teknologi informasi berupa video pembelajaran untuk kelas $\mathrm{X}, \mathrm{XI}, \mathrm{XII}$ SMA/MA di Kabupaten Gunungkidul.
Evaluasi hasil untuk mengetahui hasil produk pengembangan media berbasis teknologi informasi. Dari evaluasi hasil diperoleh bahwa Guru SosiologiSMA/MA di Kabupaten Gunungkidul dapat mengembangkan media berupa video pembelajaran sosiologi SMA/MA kelas X, XI, XII Kurikulum 2013, video pembelajaran dapat digunakan untuk menunjang pembelajaran inovatif di dalam kelas, peserta didik merasakan pembelajaran yang menyenangkan dan menarik dengan menggunakan video pembelajaran.

\section{KESIMPULAN}

Permasalahan Pembelajaran Sosiologi berbasis Kurikulum 2013 di Kabupaten Gunungkidul adalah pengembangan media pembelajaran. Media pembelajaran diperlukan sebagai sumber belajar dalam proses pembelajaran langsung dalam Kurikulum 2013 SMA/MA di Kabupaten Gunungkidul. Guru Sosiologi SMA/MA Kabupaten Gunungkidul dituntut memiliki pengetahuan dan pemahaman yang cukup tentang media pembelajaran karena berperan dalam pembelajaran sosiologi untuk mendekatkan realitas di lingkungan sosial di Gunungkidul dengan proses belajar mengajar di kelas. Pada tahun 2017 pembelajaran sosiologi SMA/MA di Kabupaten Gunungkidul diarahkan pada pembelajaran dengan Kurikulum 2013 yang menuntut guru untuk menyiapkan perencanaan pembelajaran yang matang salah satunya 
dengan pengembangan media. Guru-Guru Sosiologi SMA/MA Gunungkidul perlu dilatih secara intensif terkait dengan inovasi media pembelajaran sehingga dapat diimplementasikan dalam proses belajar mengajar. Perguruan tinggi dapat berperan dalam menyiapkan Guru Sosiologi SMA/MA Kabupaten Gunungkidul yang profesional dengan memiliki kompetensi pedagogik, profesional, kepribadian, dan sosial.

Inovasi Pembelajaran Sosiologi SMA/MA di Kabupaten Gunungkidul dilaksanakan dengan pengembangan media pembelajaran berbasis teknologi informasi. Hal ini dilakukan karena terdapat beberapa alasan yakni faktor kemampuan yang mana Guru Sosiologi SMA/MA di Kabupaten Gunungkidul tidak semua memiliki kemampuan mumpuni dalam mengembangkan media pembelajaran berbasis IT. Pada faktor geografis, jarak antar sekolah di Kabupaten Gunungkidul menjadi kendala. Faktor motivasi yang masih rendah dalam mengembangkan media pembelajaran berbasis IT. Siswa/ peserta didik belajar di sekolah masih memiliki orientasi yang terbatas pada pemenuhan aktivitas sekolah. Faktor dukungan sekolah berupa sarana dan prasarana sekolah tidak semuanya mendukung pengembangan media pembelajaran.

Pengembangan media pembelajaran berbasis teknologi informasi dalam bentuk video pembelajaran dengan aplikasi movie maker. Pengembangan dilaksanakan dengan kegiatan Focus Group Discussion, Pelatihan Pengembangan Media Pembelajaran Berbasis Teknologi Informasi melalui praktek, Simulasi Pembelajaran, dan Evaluasi Hasil. Hasil pengembangan media dapat menunjang praktek pembelajaran sosiologi bagi siswa.

\section{PERNYATAAN}

Kami ucapkan terima kasih kepada semua pihak yang telah terlibat dalam pelaksanaan inovasi pembelajaran sosiologi Kurikulum 2013 melalui pengembangan media pembelajaran berbasis teknologi informasi. Universitas Negeri Yogyakarta yang telah memberikan dukungan dana dalam penyelenggaraan program ini. MGMP Sosiologi Gunungkidul yang telah bekerjasama. Balai Pendidikan Menengah Dinas Pendidikan Pemuda dan Olahraga Kabupaten Gunungkidulyang memberikan kesempatan dan kerjasama sehingga kegiatan dapat terselenggara dengan baik. Civitas akademik SMA 1 Pathuk yang memberikan dukungan sarana dan prasarana dalam pelaksanaan program. Selanjutnya kami mengucapkan terima kasih kepada tim Jurnal Habitus dan Panitia Seminar Nasional UNS yang memberikan kesempatan untuk dapat dipublikasikannya tulisan ini. 


\section{DAFTAR PUSTAKA}

Azhar, Arsyad, (2014), Media Pembelajaran, Jakarta : PT Raja Grafindo Persada

Edgar Dale, (1969), The Cone of Learning, tersedia pada : http://sparkinsight.com/

Oemar, Hamalik, (2010), Kurikulum dan Pembelajaran, Jakarta : Bumi Aksara.

Grendi, Hendrastomo, dan Nur Endah Januarti, (2017), Inovasi Pembelajaran Sosiologi melalui Majalah Digital.

Malcom, Fleming dan W Howard Levie. (1988). Instructional Masage Design, New Jersey: Educational Technology Publications.

Peraturan Menteri Pendidikan dan Kebudayaan No 69 tahun 2013 tentang Kerangka Dasar dan Struktur Kurikulum 2013.

Sardiman A.M., (2014), Interaksi dan Motivasi Belajar Mengajar, Jakarta : PT Raja Grafindo.

Undang-Undang Nomor 20 tahun 2003 tentang Sistem Pendidikan Nasional 